\title{
THE SOLUBILITY OR DISTRIBUTION COEFFICIENT OF CARBON TETRACHLORIDE IN WATER, WHOLE BLOOD, AND PLASMA
}

\author{
BY \\ JOAN F. POWELL \\ From the Nuffield Department of Medicine, Radcliffe Infirmary, Oxford
}

In many clinical investigations, and particularly in those concerned with the toxicity of inspired industrial solvents, the solubility of the vapour in question in water, blood and plasma, is a factor of importance. To determine the solubility of vapours by experiments in vitro, it is necessary to devise an apparatus whereby a large and constantly renewed surface of liquid is brought into contact with a stream of the vapour-air mixture of given concentration. When the liquid is water this is easily achieved by passing a stream of small bubbles of the gas mixture through a column of liquid. In the case of blood and plasma this method is not practicable owing to the high viscosity of these fluids and their tendency to uncontrollable foaming. Several types of apparatus have been used in the past for overcoming these difficulties. To determine the solubility of chloroform, ethyl chloride and ethylene in blood, Nicloux (1929) used an apparatus devised by Scotti-Foglieni (1927) in which gas-air mixtures are passed over blood which is continuously agitated by vigorous stirring. To determine the solubility of carbon disulphide, McKee (1941) has used a system of two connected tonometers, one of which contains blood. The vapour-air mixture is passed through both tonometers for a few minutes, the system is then cut off from the gas supply, and rotated until equilibrium is reached.

To determine the solubility of carbon tetrachloride in blood and plasma, it was decided to construct an apparatus which maintained a constant moist gas-air flow through a rotating tonometer which contained blood or plasma. The apparatus (fig. 1) was designed by Dr. K. Mendelssohn, and a short description of it is given as an appendix.

\section{Methods}

The carbon tetrachloride-air mixtures were made up in gas cylinders under pressure. The concentration of carbon tetrachloride in the issuing gas varied between 500 and 5000 v.p.p.m., i.e. 6-32 mg. carbon tetrachloride per litre. In order that no condensation of carbon tetrachloride should take place, the partial pressure of vapour in the cylinders was kept below the saturation level. The maximum pressure allowable for the concentration required was calculated from

$P(\max )=$.

Concentration of $\mathrm{CCl}_{4}$ in air saturated at $20^{\circ} \mathrm{C}$. Concentration of $\mathrm{CCl}_{4}$ required in $\mathrm{CCl}_{4}$-air mixture

Thus, in making up the 1000 and 500 v.p.p.m. cylinders, a pressure of 120 atmospheres is allowable, but at a concentration of 2000 v.p.p.m. this is reduced to 60 atmospheres, and at a-concentration of 5000 v.p.p.m., to 24 atmospheres.

Analyses of the carbon tetrachloride-air mixture were made by passing a measured stream of gas into a known volume of toluene. The latter was contained in an absorption bottle with a sintered glass plate. An aliquot of the toluene solution was treated with pyridine and alkali (Habgood and Powell, 1944).

\section{Water}

Carbon tetrachloride-air mixture was bubbled through 40 to $60 \mathrm{ml}$. of distilled water contained in a gas absorption bottle with a sintered glass plate. Equilibrium was reached in $\frac{3}{4}$ hour with a gas flow of $50 \mathrm{ml}$. per minute. By connecting the gas supply to the outlet tube of the bottle, the liquid was transferred to a calibrated measuring cylinder. The latter had a ground glass neck, and contained a small measured volume of toluene, varying between 2 and $5 \mathrm{ml}$. The measuring cylinder was then stoppered and shaken at intervals for about 15 minutes until the toluene extraction was complete. The liquid was then allowed to settle, the toluene layer pipetted off and analysed for carbon tetrachloride by treatment with pyridine and alkali as before.

\section{Blood and Plasma}

Blood samples of 100-200 ml. were obtained from normal volunteers, oxalate or heparin being used as an anticoagulant. The haemoglobin content was measured by Haldane's carboxyhaemoglobin method. In a few cases the fat content was also determined by the method of Bloor (1928). 


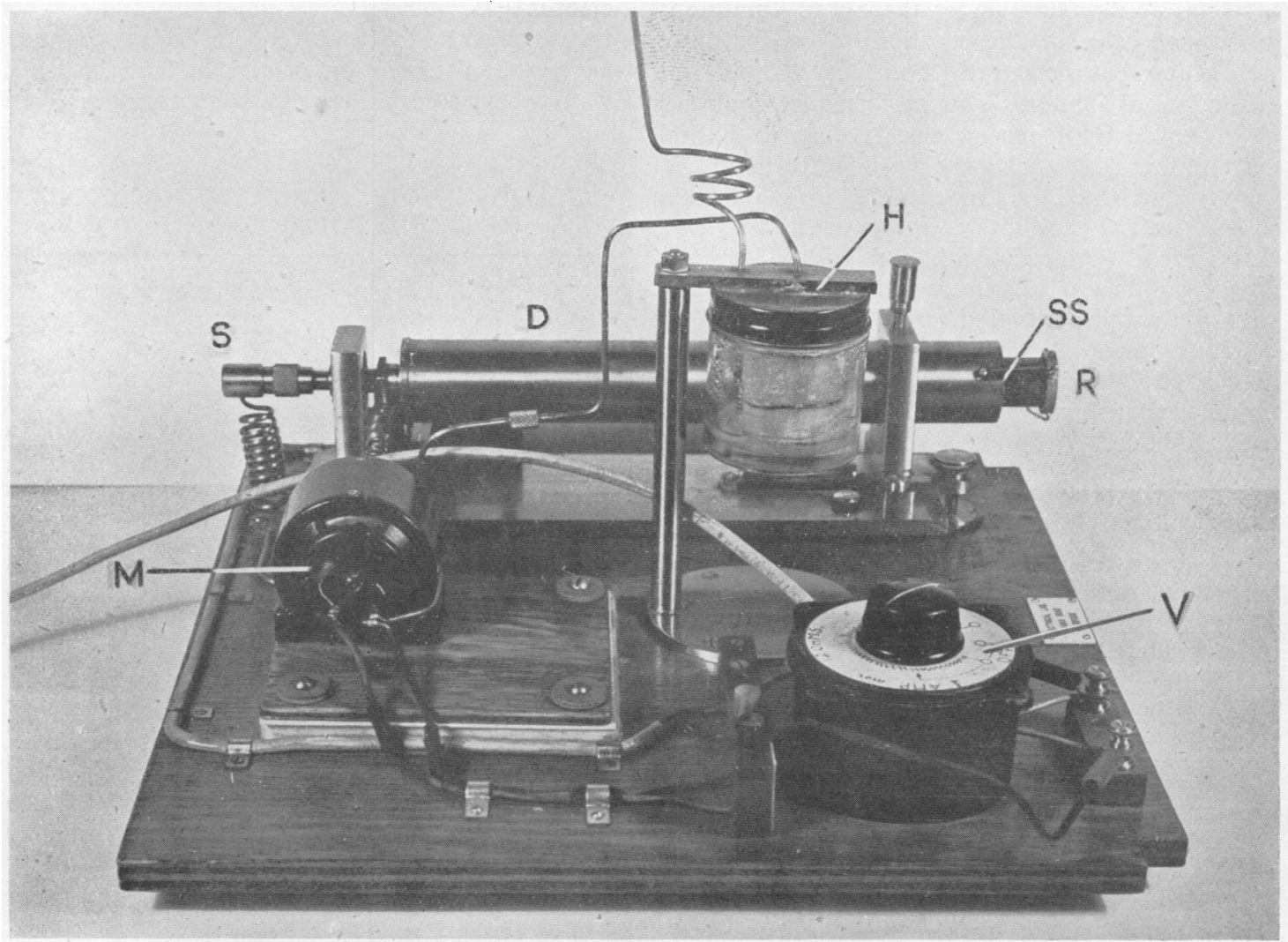

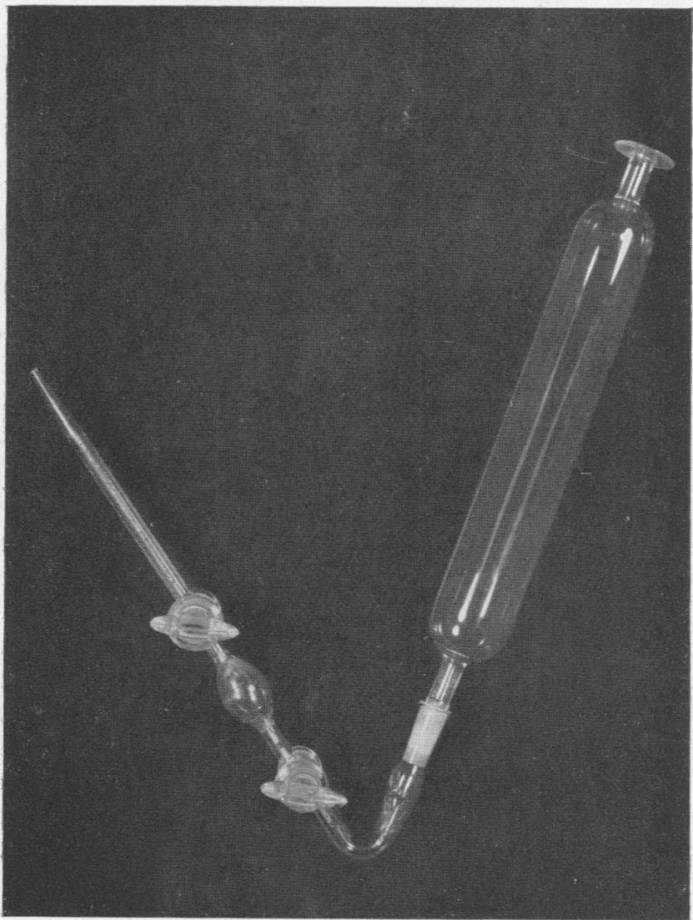

FIG. 2.-Tonometer and sampling pipette.
To determine the amount of carbon tetrachloride absorbed from a given gas mixture, the water in the humidifier was first saturated with the gas mixture by passing through a slow stream, i.e. about $50 \mathrm{ml}$. per minute, for $\frac{1}{2}$ hour. The tonometer was then loaded with $15-20 \mathrm{ml}$. of blood or plasma, which was generally enough for three analyses. The carbon tetrachloride-air mixture was then passed through the whole system at a rate of $250 \mathrm{ml}$. per minute, with the drum rotating at a speed of 100 120 revs. per minute. Blood samples were withdrawn after 1 hour, $1 \frac{1}{2}$ hours and 2 hours. For this purpose the pipette shown in fig. 2 was used-a modification of that described by McKee (1941). The pipette was first washed out with the gas mixture and then connected to the tonometer by means of the small ground glass joint. By tilting the tonometer slightly and applying a slight pressure from the gas cylinder to the flattened end, blood was forced to about midway up the bulb of the pipette. The taps were then turned off, and the tonometer disconnected. Pressure was then applied to the wide end of the pipette, and the blood forced into the bulb and up to the drawn out end. After adjusting the level, the blood was delivered into a stream distillation apparatus (Habgood and Powell, 1944) and its carbon tetrachloride content determined by extraction of the distillate with toluene and treatment of the toluene extract with pyridine and alkali. 
It was found that, under the above conditions, 90-95 per cent. of the equilibrium concentration was achieved at the end of $\frac{1}{2}$ hour, and 100 per cent. at the end of 1 hour. This performance could not be improved by increasing the gas flow to $500 \mathrm{ml}$. per minute. Decreasing the gas flow to $100 \mathrm{ml}$. per minute lengthened the time required for equilibrium to 2 hours.

It is seen that even with a relatively large gas flow, equilibrium takes considerably longer than with the simple bubbling arrangement which was used for water. A large proportion of the gas will take a straight course through the centre of the tonometer without coming into appreciable contact with the liquid.

\section{Water \\ Results}

The results obtained by equilibrating water with carbon tetrachloride-air mixtures at $20^{\circ} \mathrm{C}$. and $37^{\circ} \mathrm{C}$. are shown in fig. 3 . The amount of carbon

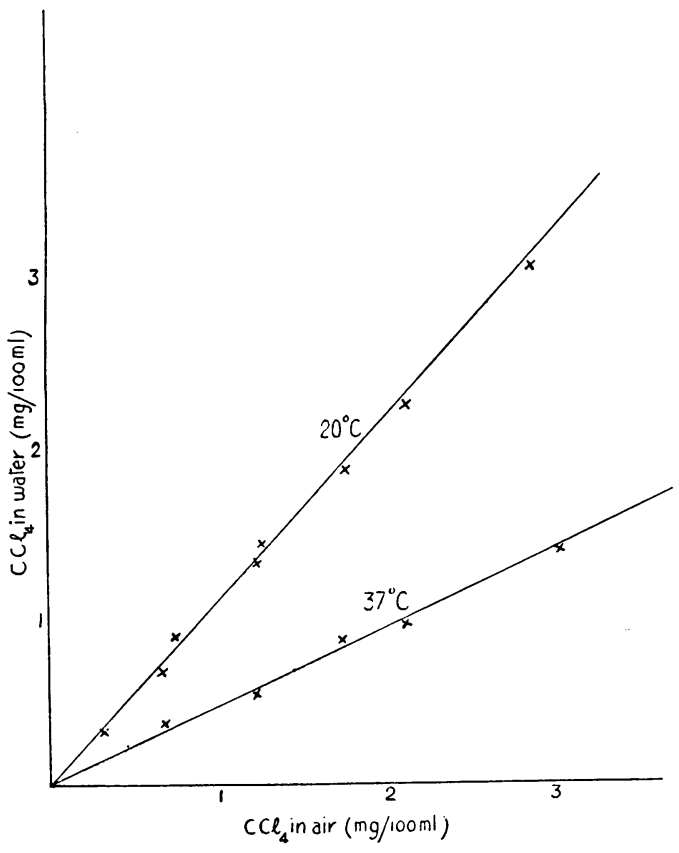

FIG. 3.-Solubility of carbon tetrachloride in water at $20^{\circ} \mathrm{C}$. and $37^{\circ} \mathrm{C}$.

tetrachloride absorbed is directly proportional to its concentration in the gas, the Ostwald solubility, or distribution coefficient, i.e. concentration in the liquid/concentration in the gas, being 1.07 at $20^{\circ} \mathrm{C}$. and 0.46 at $37^{\circ} \mathrm{C}$.

It is interesting to note that a saturated aqueous solution of carbon tetrachloride at $20^{\circ} \mathrm{C}$. contains $80 \mathrm{mg}$. per $100 \mathrm{ml}$. Here the concentration of carbon tetrachloride in the gas phase is $76 \mathrm{mg}$. per $100 \mathrm{ml}$., so that the distribution coefficient is 1.05. Similarly at $37^{\circ} \mathrm{C}$. we have found the solubility of carbon tetrachloride in water to be $68 \mathrm{mg}$. per $100 \mathrm{ml}$., with a concentration in the gas phase of $152 \mathrm{mg}$. per $100 \mathrm{ml}$., so that the distribution coeffi- cient is $\mathbf{0 . 4 5}$. These values practically coincide with those found at the lower end of the scale, so it is. likely that the solution of carbon tetrachloride in water obeys Henry's law at all concentrations.

TABLE 1A

SOLUBILITY OF CARBON TETRACHLORIDE IN BLOOD AT $20^{\circ} \mathrm{C}$. AND $37^{\circ} \mathrm{C}$.

\begin{tabular}{|c|c|c|c|c|c|}
\hline \multirow{2}{*}{ Donor } & \multirow{2}{*}{$\begin{array}{c}\mathrm{CCl}_{4} \text { in air } \\
\mathrm{mg} . / 100 \mathrm{ml} . \\
(0.64 \mathrm{mg} . / \\
100 \mathrm{ml} .=1,000 \\
\text { v.p.p.m. })\end{array}$} & \multicolumn{2}{|c|}{$\mathrm{CCl}_{4}$ in blood } & \multicolumn{2}{|c|}{$\mathrm{C}$ blood $\mathrm{C}$ air } \\
\hline & & $20^{\circ} \mathrm{C}$. & $37^{\circ} \mathrm{C}$. & $20^{\circ} \mathrm{C}$. & $37^{\circ} \mathrm{C}$. \\
\hline $\begin{array}{l}\text { 1. Haemo- } \\
\text { globin, } \\
112 \%\end{array}$ & $\begin{array}{l}0.33 \\
0.65 \\
1 \cdot 32 \\
2 \cdot 01 \\
2 \cdot 86\end{array}$ & $\begin{array}{l}1 \cdot 72 \\
3 \cdot 10 \\
6 \cdot 67 \\
10 \cdot 2 \\
14 \cdot 3\end{array}$ & $\begin{array}{l}1.59 \\
1.59 \\
4.07 \\
7.06\end{array}$ & $\begin{array}{l}5 \cdot 2 \\
4 \cdot 8 \\
5 \cdot 1 \\
5 \cdot 1 \\
5 \cdot 0\end{array}$ & $\begin{array}{l}\overline{2 \cdot 4} \\
2 \cdot 3 \\
2 \cdot 5 \\
2 \cdot 5\end{array}$ \\
\hline $\begin{array}{l}\text { 2. Haemo- } \\
\text { globin, } \\
90 \%\end{array}$ & $\begin{array}{l}0 \cdot 34 \\
0 \cdot 69 \\
1 \cdot 20 \\
3 \cdot 40\end{array}$ & $\begin{array}{c}1 \cdot 38 \\
2 \cdot 58 \\
4 \cdot 54 \\
12 \cdot 8\end{array}$ & $\begin{array}{l}\overline{1 \cdot 37} \\
2 \cdot 42 \\
6 \cdot 20\end{array}$ & $\begin{array}{l}4 \cdot 0 \\
3 \cdot 8 \\
3 \cdot 7 \\
3 \cdot 8\end{array}$ & $\begin{array}{l}-\overline{2 \cdot 0} \\
1.9 \\
1 \cdot 8\end{array}$ \\
\hline $\begin{array}{l}\text { 3. Haemo- } \\
\text { globin, } \\
95 \%\end{array}$ & $\begin{array}{l}0 \cdot 64 \\
1 \cdot 10 \\
2 \cdot 36 \\
2 \cdot 77\end{array}$ & $\begin{array}{l}2 \cdot 87 \\
5 \cdot 25 \\
10 \cdot 5 \\
13 \cdot 4\end{array}$ & $\begin{array}{l}\overline{2 \cdot 35} \\
\overline{5 \cdot 9}\end{array}$ & $\begin{array}{l}4 \cdot 6 \\
4 \cdot 8 \\
4 \cdot 4 \\
4 \cdot 8\end{array}$ & $\frac{\overline{2 \cdot 1}}{2 \cdot 1}$ \\
\hline $\begin{array}{l}\text { 4. Haemo- } \\
\text { globin, } \\
90 \%\end{array}$ & $\begin{array}{l}0 \cdot 33 \\
0 \cdot 65 \\
1 \cdot 32 \\
2 \cdot 01 \\
2 \cdot 86\end{array}$ & $\begin{array}{l}1 \cdot 76 \\
3 \cdot 27 \\
6 \cdot 67 \\
10 \cdot 2 \\
14 \cdot 3\end{array}$ & $\begin{array}{l}\overline{1 \cdot 58} \\
3 \cdot 07 \\
4 \cdot 90 \\
7 \cdot 06\end{array}$ & $\begin{array}{l}5 \cdot 3 \\
5 \cdot 0 \\
5 \cdot 1 \\
5 \cdot 1 \\
5 \cdot 0\end{array}$ & $\begin{array}{l}-\overline{2 \cdot 4} \\
2 \cdot 3 \\
2 \cdot 5 \\
2 \cdot 5\end{array}$ \\
\hline
\end{tabular}

TABLE 1B

SOLUBILITY OF CARBON TETRACHLORIDE IN BLOOD AT $20^{\circ} \mathrm{C}$.

\begin{tabular}{|c|c|c|c|}
\hline Donor & $\begin{array}{c}\mathrm{CCl}_{4} \text { in air, } \\
\mathrm{mg} . / 100 \mathrm{ml} . \\
(0.64 \mathrm{mg} . / \\
100 \mathrm{ml}=1,000 \\
\text { v.p.p.m. }\end{array}$ & $\begin{array}{l}\mathrm{CCl}_{4} \text { in } \\
\text { blood, } \\
20^{\circ} \mathrm{C} .\end{array}$ & $\begin{array}{l}\text { C blood/ } \\
\text { C air, } \\
20^{\circ} \text { C. }\end{array}$ \\
\hline $\begin{array}{l}\text { 5. Haeomglobin, } \\
108 \%\end{array}$ & $\begin{array}{l}0.34 \\
0 \cdot 63 \\
1 \cdot 20\end{array}$ & $\begin{array}{l}1 \cdot 40 \\
2 \cdot 32 \\
4 \cdot 80\end{array}$ & $\begin{array}{l}4 \cdot 1 \\
3 \cdot 7 \\
4 \cdot 0\end{array}$ \\
\hline $\begin{array}{l}\text { 6. Haemoglobin, } \\
90 \%\end{array}$ & $\begin{array}{l}0 \cdot 34 \\
0 \cdot 61 \\
1 \cdot 27 \\
3 \cdot 21\end{array}$ & $\begin{array}{c}1 \cdot 28 \\
2 \cdot 32 \\
5 \cdot 60 \\
13 \cdot 0\end{array}$ & $\begin{array}{l}3 \cdot 8 \\
3 \cdot 8 \\
4 \cdot 4 \\
4 \cdot 1\end{array}$ \\
\hline $\begin{array}{l}\text { 7. Haemoglobin, } \\
96 \%\end{array}$ & $\begin{array}{l}0 \cdot 75 \\
1 \cdot 22\end{array}$ & $\begin{array}{l}2 \cdot 70 \\
4 \cdot 40\end{array}$ & $\begin{array}{l}3 \cdot 6 \\
3 \cdot 7\end{array}$ \\
\hline
\end{tabular}

As is seen from Tables $1 \mathrm{~A}$ and $1 \mathrm{~B}$, the distribution coefficient of carbon tetrachloride between blood and air varied between 3.6 and 5.2 at $20^{\circ} \mathrm{C}$. and between 1.8 and 2.5 at $37^{\circ} \mathrm{C}$. Fairly constant values, within the limits of experimental error, were obtained from each blood sample. From the small amount of data obtained (Table 2), it seems likely that a correlation exists between the amount of carbon tetrachloride absorbed and the blood fat, although more experimental data is needed to establish this point.

There does not, however, appear to be any direct correlation between the red cell content and the amount of carbon tetrachloride absorbed, cf. cases 
TABLE 2

SOLUBILITY OF CARBON TETRACHLORIDE IN BLOOD SPECIMENS OF DIFFERENT FAT AND HAEMOGLOBIN CONTENTS

\begin{tabular}{|c|c|c|c|c|}
\hline $\begin{array}{c}\mathrm{CCl}_{4} \text { in } \\
\text { air }(\mathrm{mg} . / \\
100 \mathrm{ml} .)\end{array}$ & $\begin{array}{c}\mathrm{CCl}_{4} \text { in } \\
\text { blood(mg./ } \\
100 \mathrm{ml} .)\end{array}$ & $\mid \begin{array}{c}\mathrm{C} \text { blood} / \\
\mathrm{C} \text { air }\end{array}$ & $\begin{array}{l}\text { Haemo- } \\
\text { globin } \\
\text { (\% Hal- } \\
\text { dane) }\end{array}$ & $\begin{array}{c}\text { Blood fat } \\
\text { (mg./ } \\
100 \mathrm{ml} .)\end{array}$ \\
\hline 0.60 & $\begin{array}{l}1.95 \\
2.53 \\
2.15\end{array}$ & $\begin{array}{l}3 \cdot 3 \\
4 \cdot 2 \\
3 \cdot 6\end{array}$ & $\begin{array}{r}90 \\
98 \\
108\end{array}$ & $\begin{array}{l}384 \\
550 \\
540\end{array}$ \\
\hline $3 \cdot 44$ & $\begin{array}{l}12.5 \\
12.0 \\
15.5\end{array}$ & $\begin{array}{l}3 \cdot 6 \\
3 \cdot 5 \\
4 \cdot 5\end{array}$ & $\begin{array}{l}92 \\
90 \\
94\end{array}$ & $\begin{array}{l}394 \\
384 \\
500\end{array}$ \\
\hline $1 \cdot 32$ & $\begin{array}{l}4 \cdot 40 \\
5 \cdot 10\end{array}$ & $\begin{array}{l}3 \cdot 3 \\
4 \cdot 0\end{array}$ & $\begin{array}{l}90 \\
92\end{array}$ & $\begin{array}{l}384 \\
500\end{array}$ \\
\hline
\end{tabular}

1, 4 and 7 in Tables $1 \mathrm{~A}$ and 1B. Furthermore, blood obtained from a patient with hypochromic anaemia and a haemoglobin of 60 per cent. absorbed $7.03 \mathrm{mg}$. carbon tetrachloride per $100 \mathrm{ml}$. in contact with a gas mixture containing $1.32 \mathrm{mg}$. per $100 \mathrm{ml}$., and $3.40 \mathrm{mg}$. per $100 \mathrm{ml}$. in contact with a mixture containing $0.70 \mathrm{mg}$. per $100 \mathrm{ml}$. This gave high values for the distribution coefficient of $5 \cdot 2$ and 4.9 respectively.

The distribution coefficient between plasma and air varied between $6 \cdot 2$ and $10 \cdot 7$ at $20^{\circ} \mathrm{C}$.

A comparison of the distribution coefficient of whole blood with plasma obtained from the same specimen is given in Table 3 and in fig. 4. These results indicate that the amount of carbon tetrachloride absorbed by the red cell is almost negligible. In two cases, small negative values were calculated from the experimental data-this was, of course, due to a too high value for the plasma, associated with a too low value for the corresponding whole blood. In the last colume of Table 3, theoretical values have been calculated for the carbon tetrachloride content of the red cells, assuming that the amount absorbed depends only on their water content.

TABLE 3

SOLUBILITY OF CARBON TETRACHLORIDE IN WHOLE BLOOD AND PLASMA AT $20^{\circ} \mathrm{C}$.

\begin{tabular}{|c|c|c|c|c|c|}
\hline \multicolumn{3}{|c|}{$\begin{array}{l}\text { Concentration of } \\
\mathrm{CCl}_{4}(\mathrm{mg} . / 100 \mathrm{ml} .)\end{array}$} & \multirow{2}{*}{$\begin{array}{l}\text { Haema- } \\
\text { tocrit }\end{array}$} & \multicolumn{2}{|c|}{$\begin{array}{c}\mathrm{CCl}_{4} \text { in red cells } \\
(\mathrm{mg} . / 100 \mathrm{ml} .)\end{array}$} \\
\hline Air & Blood & Plasma & & $\begin{array}{c}\text { Calculated } \\
\text { from ex- } \\
\text { perimental } \\
\text { results }\end{array}$ & $\begin{array}{l}\text { Calculated } \\
\text { from } \\
\text { water } \\
\text { content }\end{array}$ \\
\hline $\begin{array}{l}1 \cdot 32 \\
0 \cdot 69 \\
1 \cdot 20 \\
0 \cdot 33 \\
0 \cdot 65 \\
1 \cdot 32 \\
2 \cdot 36 \\
0 \cdot 33 \\
0 \cdot 65 \\
1 \cdot 32\end{array}$ & $\begin{array}{c}5 \cdot 10 \\
2 \cdot 58 \\
4 \cdot 54 \\
1 \cdot 76 \\
3 \cdot 27 \\
6 \cdot 15 \\
15 \cdot 0 \\
1 \cdot 72 \\
3 \cdot 10 \\
6 \cdot 67\end{array}$ & $\left.\begin{array}{c}8 \cdot 20 \\
4 \cdot 88 \\
7 \cdot 70 \\
2 \cdot 94 \\
6 \cdot 00 \\
10 \cdot 0 \\
25 \cdot 0 \\
2 \cdot 72 \\
5 \cdot 66 \\
12 \cdot 2\end{array}\right\}$ & $\begin{array}{l}41 \\
43\end{array}$ & $\begin{array}{l}+0.3 \\
-0.5 \\
+0.4 \\
+0.1 \\
-0.3 \\
+0.6 \\
+1.2 \\
+0.7 \\
+0.6 \\
+1.1\end{array}$ & $\begin{array}{l}0.8 \\
0.4 \\
0 \cdot 7 \\
0 \cdot 2 \\
0 \cdot 4 \\
0 \cdot 8 \\
1 \cdot 4 \\
0 \cdot 2 \\
0 \cdot 4 \\
0.8\end{array}$ \\
\hline
\end{tabular}

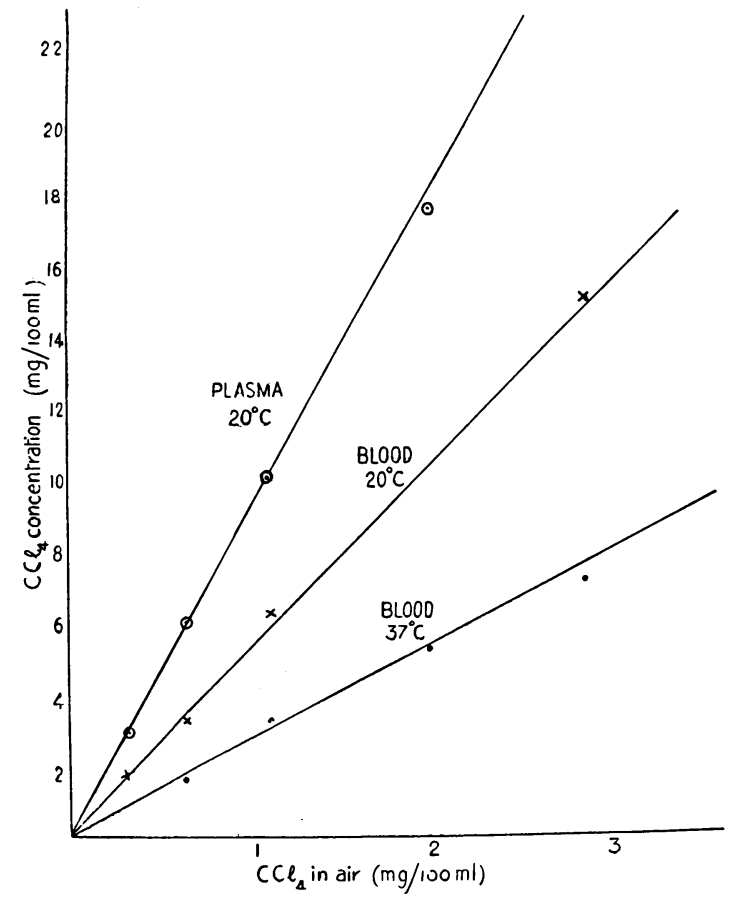

FIG. 4.-Solubility of carbon tetrachloride in whole blood at $20^{\circ} \mathrm{C}$. and $37^{\circ} \mathrm{C}$., and in plasma at $20^{\circ} \mathrm{C}$.

It was found that prolonged contact, i.e. up to $4 \frac{1}{2}$ hours, with the gas mixture did not increase the amount of carbon tetrachloride absorbed by a given blood specimen, which practically removed the possibility that passage of carbon tetrachloride into the red cell is merely a slow process. Further, it was found that totally haemolysed blood, i.e. blood which had been kept at $0^{\circ} \mathrm{C}$. for 2-3 weeks and shaken vigorously at intervals, absorbed the same amount of carbon tetrachloride from a given air mixture as it did before this treatment-which establishes the non-affinity of the red cell constituents for carbon tetrachloride.

An interesting result was obtained when the relative proportion of plasma to red cells was increased by diluting 1 volume of blood with 1 volume of plasma from the same specimen. When the whole blood, 'diluted' blood and plasma were equilibrated with an air mixture containing $3 \mathrm{mg}$. carbon tetrachloride per $100 \mathrm{ml}$., concentrations of $11 \cdot 7,15.0$ and $20.0 \mathrm{mg}$. carbon tetrachloride respectively were found. The concentration in the 'diluted' blood was almost exactly midway between blood and plasma.

\section{Discussion}

The results obtained for water do not require further comment. In the case of blood and plasma, it is rather surprising to note the very small affinity of the red cell for carbon tetrachloride-in fact, the experimental data indicate that the small amount of carbon tetrachloride actually absorbed by red cells can be accounted for by their water content. It is 
interesting to compare these results with those obtained by Nicloux (1929) for chloroform. This author finds that the distribution coefficient of chloroform between water and air varies between 15 and 4 in the temperature range $13^{\circ} \mathrm{C}$. to $40^{\circ} \mathrm{C}$., and the air-concentration range $5-12 \mathrm{mg}$. per $100 \mathrm{ml}$. The distribution coefficient between human blood and air was found to be 20 at $13^{\circ} \mathrm{C}$., 16 at $30^{\circ} \mathrm{C}$., and 10 at $37^{\circ} \mathrm{C}$., and ox blood gave similar results in the same concentration range. Unfortunately no results are available for a lower range of concentrations comparable with those used in the present study for carbon tetrachloride. Since, however, from Nicloux's results, the distribution coefficient at a given temperature is practically constant throughout the range investigated, it is likely that the same relationships hold at lower concentrations.

In the case of serum obtained from ox blood, Nicloux has found values for the distribution coefficient to vary between 20 and 8 in the temperature range $13^{\circ} \mathrm{C}$. to $27^{\circ} \mathrm{C}$. It therefore appears that, in marked contrast to their behaviour with carbon tetrachloride, red cells absorb chloroform to approximately the same extent as does serum. This is supported by the experiments of van Dessel (1923), who added small amounts of chloroform to oxalated human blood, and recovered 52 per cent. of the amount added in the plasma, and 48 per cent. in the red cells. In blood taken from patients under chloroform anaesthesia, however, it should be noted that the same investigator found approximately 70 per cent. of the chloroform in the plasma. Scotti Foglieni (1930) found that the haemoglobin content of blood is of primary importance in determining the amount of chloroform and of ethyl chloride which it will absorb. This is supported by the evidence that suspensions of pure haemoglobin in water absorb quantities of chloroform and ethyl chloride proportional to the amount of haemoglobin present. The presence of red cell envelopes and stroma does not influence these results. The same author also states that serum free from traces of haemoglobin gives the same solubility coefficient as pure water-a very surprising observation in view of the very great solubility of chloroform in fatty media.

The results obtained in the present study indicate that the plasma fat is the determining factor in the absorption of carbon tetrachloride, and that the haemoglobin content reduces the absorption in a purely mechanical way, i.e. by decreasing the relative amount of plasma. Carbon tetrachloride is chemically a relatively inactive compound compared with chloroform, and its non-affinity for haemoglobin may be thus accounted for. It is true that red cells contain quite large amounts of ' lipoid' substance, which might be expected to dissolve chlorhydrocartons readily. This 'lipoid' material is not, however, in the form of simple fats, but consists mainly of phospholipoids (Macey, 1938), in which carbon tetrachloride may be relatively insoluble. The observation of Scotti Foglieni that the red cell constituents other than haemoglobin do not influence the absorption of chloroform, is of relevance in this connection.

\section{Summary}

The distribution coefficient of carbon tetrachloride between water and air is 1.04 at $20^{\circ} \mathrm{C}$. and 0.46 at $37^{\circ} \mathrm{C}$. The air concentrations used varied between 0.33 and $3.44 \mathrm{mg}$. per $100 \mathrm{ml}$. (500-5,000 v.p.p.m.). The' distribution coefficient' is defined as concentration in the liquid/concentration in the gas.

The distribution coefficient between blood and air is constant in a given specimen throughout the above concentration range. The coefficient in a series of specimens varied between 3.6 and 5.2 at $20^{\circ} \mathrm{C}$. and between 1.8 and 2.5 at $37^{\circ} \mathrm{C}$.

The amount of carbon tetrachloride absorbed by the red cell appears to be negligible.

The small quantity of data obtained suggests that the amount of carbon tetrachloride absorbed from a given air mixture is proportional to the plasma fat concentration.

\section{Acknowledgments}

I wish to thank Dr. K. Mendelssohn for his help in designing the equilibration apparatus, and Miss Sheila Habgood for assisting with the blood fat estimations.

\section{APPENDIX}

\section{The Equilibration Apparatus (see Fig. 1)}

\section{K. MendelsSOHN}

The gas mixture is first passed through a flowmeter and then enters the humidifier $(H)$. This consists of two concentric compartments separated by a cylinder of wire netting covered with a few layers of gauze bandage. The latter is kept moist by capillary attraction. The gas mixture entering the inner compartment has to pass the moist screen before it can reach the outlet tube which opens into the outer compartment. From the humidifier, the gas passes into the rotation drum (D), which houses the tonometer (see fig. 2). Junction between the stationary inlet tube and the rotating drum is effected by a close but not tight fitting metal sleeve (S), which is kept in position by the coiled inlet tube. Since the flow resistance of the whole arrangement is kept very low, the leak through this junction is negligible. The tonometer is kept in position, its flattened end pressed into the drum by the ring (R) and the springs (SS). From the tonometer, the gas mixture escapes into the atmosphere. The small motor $(\mathrm{M})$ rotates the drum through a worm-drive, and its speed is controlled by the variable resistance (V). The component parts are mounted on a plywood board, which is fitted into an ordinary incubator, the leads from the accumulator and the gas supply being passed through a hole in the top of the incubator. A detailed description of the instrument and its performance will be given later.

\section{REFERENCES}

Bloor, W. R. (1928). J. biol. Chem., 77, 53.

Habgood, S., and Powell, J. F. (1944). Brit. J. industr. Med., 1, 39. Macey, I. G. (1938). J. biol. Chem., 122, 515 .

McKee, R. W. (1941). J. industr. Hyg., 23, 484

Scotti Foglieni, L. (1927). C.R. Soc. Biol., Paris, 97, 1561.

van Dessel, A. (1923). Arch. intern. Pharm. Ther., 27, 1. 